\title{
PENGARUH NPL DAN LDR TERHADAP PROFITABILITAS DENGAN CAR SEBAGAI VARIABEL MEDIASI PADA LPD KOTA DENPASAR
}

\author{
Nanik Sri Dwi Wulandari ${ }^{1}$ \\ I.B.A Purbawangsa ${ }^{2}$ \\ ${ }^{1,2}$ Fakultas Ekonomi dan Bisnis Universitas Udayana (Unud), Bali, Indonesia \\ e-mail:nanikwulandari21@gmail.com
}

\begin{abstract}
ABSTRAK
Tujuan penelitian ini untuk menganalisis pengaruh $N P L$ dan $L D R$ terhadap $C A R$, serta untuk menganalisis pengaruh NPL, LDR, dan CAR terhadap profitabilitas pada LPD di Kota Denpasar. Populasi yang digunakan adalah LPD se-Kota Denpasar sebanyak35 LPD. Metode penentuan sampel menggunakan metode purposive sampling yaitu penentuan sampeldengankriteria yakniLPD se-Kota Denpasar yang masih aktif, sehingga sampel penelitianyaitu berjumlah 33 LPD. Teknik analisis data yang digunakan untuk menguji bagaimana pengaruh NPL dan LDR terhadap profitabilitas dengan CAR sebagai variabel mediasi adalah teknik analisis jalur atau path analysis. Sebelum melakukan analisis jalur tersebut, maka terlebih dahulu dilakukan uji asumsi klasik yaitu uji normalitas, multikolinearitas, heteroskedastisitas, dan autokorelasi.Hasil analisis dalam penelitian ini menunjukkan bahwa NPLtidak berpengaruh signifikan pada CAR, LDRberpengaruh negatif dan signifikan pada CAR, NPLberpengaruh negatif dan signifikan pada profitabilitas, LDR dan CAR berpengaruh positif dan signifikan pada profitabilitas LPD di Kota Denpasar.
\end{abstract}

Kata kunci: $N P L, L D R, C A R$, Profitabilitas

\begin{abstract}
The purpose of this study was to analyze the effect of NPL and LDR on CAR, as well as to analyze the effect of NPL, LDR, and CAR on profitability at LPDs in Denpasar City. The population used is LPD in Denpasar City as many as 35 LPDs. The method of determining samples using purposive sampling method is the determination of samples with criteria, namely LPD throughout Denpasar City which is still active, so that the sample of the study is 33 LPDs. Data analysis techniques used to examine how the influence of NPL and LDR on profitability with CAR as a mediating variable are path analysis techniques. Before analyzing the pathway, the first classical assumption is tested, namely normality, multicollinearity, heteroscedasticity, and autocorrelation. The results of the analysis in this study indicate that NPL does not have a significant effect on the CAR, LDR has a negative and significant effect on the CAR, NPL has a negative and significant effect on profitability, LDR and CAR has a positive and significant effect on the profitability of LPD in Denpasar City.

Keywords: NPL, LDR, CAR, Profitability
\end{abstract}




\section{PENDAHULUAN}

LPD di Bali semakin berkembang dari sisi jumlah dan keuntungan yang dicapai per tahun. Penelitian mengenai LPD ini dilakukan karena LPD mempunyai keunikan tersendiri yaitu hanya terdapat di Bali dan mempunyai peran dalam masalah keuangan masyarakat desa pakraman di Bali (Sudiantari, 2011). LPD jika dibandingkan dengan lembaga keuangan lainnya yaitu merupakan lembaga keuangan yang bersifat sangat khas dan khusus dilihat dari dasar konstitusional, dasar hukum, asal-usul dan tujuan, serta pola kerja yang sangat berbeda dengan lembaga keuangan lainnya (Nurjaya, 2011:77).

Profitabilitas mempunyai arti penting bagi LPD untuk mempertahankan kelangsungan hidupnya dalam jangka panjang, karena profitabilitas menunjukkan apakah LPD tersebut mempunyai prospek yang baik kedepannya (Wiagustini, 2014:86). Dengan demikian setiap LPD akan selalu berusaha meningkatkan profitabilitasnya, dimana semakin tinggi profitabilitas suatu LPD maka kinerja LPD tersebut dapat dikatakan dengan baik karena telah beroperasi secara efektif dan efisien. Profitabilitas dalam penelitian ini diukur dengan return on assets (ROA). ROA adalah rasio yang menunjukkan return atas jumlah aktiva yang digunakan dalam perusahaan (Kasmir, 2011:201). Profitabilitas LPD dapat dipengaruhi oleh berbagai macam faktor seperti non performing loan (NPL), loan to deposit ratio (LDR), dancapital adequacy ratio (CAR).

Non performing loan (NPL)merupakan rasio untuk mengukur besarnya tingkat kredit bermasalah yang terjadi pada suatu bank. Besarnya persentase NPL haruslah menjadi perhatian pihak manajemen karena kredit bermasalah yang 
semakin meningkat dapat membahayakan kesehatan bank tersebut. Kredit yang disalurkan oleh bank memiliki risiko terjadinya gagal bayar oleh debitur. Besarnya NPL yang diperbolehkan oleh Bank Indonesia saat ini adalah maksimal 5 persen. Semakin besar tingkat NPL menunjukkan bahwa bank tersebut tidak profesional dalam pengelolaan kreditnya yang akan berdampak pada kerugian bank.

Pentingnya LPD dalam menjaga kepercayaan masyarakat sehingga tingkat kesehatan LPD perlu diperhatikan karena kegiatan utama LPD adalah menghimpun dana dari masyarakat yang kemudian disalurkan kembali berupa pemberian kredit dengan tujuan agar memperoleh pendapatan. Pemeliharaan kesehatan LPD yaitu dengan menjaga likuiditasnya. Likuiditas diartikan sebagai kemampuan sebuah bank untuk memenuhi kewajibannya pada pihak ketiga yang ditagih dalam waktu dekat dan termasuk kewajiban terhadap biaya-biaya yang dikeluarkan bank (Sudirman, 2013:69). LDR dapat digunakan sebagai ukuran dalam menilai kemampuan bank dalam menjalankan usaha atau kegiatan operasionalnya. LDR menyatakan seberapa jauh kemampuan bank membayar kembali penarikan yang dilakukan nasabah deposan dengan mengandalkan kredit yang diberikan sebagai sumber likuiditasnya (Sianturi, 2012). Penting bagi pihak manajemen untuk memperhatikan persentase rasio LDR tetap berada pada batas aman yang telah ditentukan oleh Bank Indonesia. Berdasarkan Peraturan Bank Indonesia No. 15/7/PBI/2013 standar LDR yaitu 78 persen - 92 persen. Jika angka rasio LDR berada dibawah 78 persen maka dapat dikatakan bahwa bank tersebut tidak dapat menyalurkan kembali dengan baik seluruh dana yang telah 
dihimpun. Jika rasio LDR bank mencapai lebih dari 92 persen maka total kredit yang disalurkan oleh bank tersebut telah melebihi dana yang dihimpun.

Modal pada bank memiliki peran yang sangat penting. Kecukupan modal dapat diukur dengan menggunakan rasio Capital Adequacy Ratio (CAR). Penting bagi pihak manajemen untuk memperhatikan besarnya CAR yang dimiliki agar bank tidak kekurangan dana dan juga tidak kelebihan dana. Modal merupakan sumber utama pembiayaan kegiatan operasional bank dan juga berperan sebagai penyangga kemungkinan terjadinya risiko kerugian. Semakin besar modal yang dimiliki maka semakin kuat bank tersebut dalam mengahadapi risiko-risiko yang tidak terduga sehingga bank dapat meningkatkan kepercayaan masyarakat (Anjani dan Purnawati, 2014). Namun bank yang memiliki CAR terlalu tinggi dapat mengakibatkan terjadinya idle fund, yaitu terdapat banyaknya dana yang menganggur yang tidak dapat dimanfaatkan oleh manajemen bank tersebut. Modal bank terdiri dari modal inti dan modal pelengkap (Idroes, 2008:69). Berdasarkan peraturan Bank Indonesia No.15/12/PBI/2013, permodalan minimum yang harus dimiliki oleh suatu bank adalah 8 persen. CAR sebagai variabel mediasi pengaruh NPL dan LDR terhadap profitabilitas, hal ini dikarenakan CAR yang merupakan rasio permodalan menjadi faktor penentu berjalannya kegiatan operasional bank dalam menghimpun dana dan menyalurkannya kembali.

Jika NPL suatu bank terus meningkat maka akan mempengaruhi permodalan bank karena bank harus menyediakan dana untuk memenuhi Penyisihan Penghapusan Aktiva Produktif (PPAP) yang terbentuk (Pauzi, 2010). Modal bank yang seharusnya dapat digunakan untuk investasi lainnya menjadi 
berkurang akibat dari adanya pembentukan PPAP, sehingga dapat dikatakan bahwa NPL berpengaruh negatif dan signifikan terhadap CAR. Penelitian yang dilakukan oleh Margaretha dan Diana (2011), Tracey (2011), dan Buyuksalvarci dan Hasan (2011) menemukan hasil bahwa NPL memiliki pengaruh negatif signifikan terhadap CAR. Berbeda dengan penelitian yang dilakukan oleh Anjani dan Purnawati (2014) menemukan hasil penelitian bahwa NPL tidak berpengaruh signifikan terhadap CAR sedangkan Fitrianto dan Mawardi (2006) menemukan bahwa NPL memiliki hubungan negatif dan tidak signifikan terhadap CAR.

Penelitian mengenai NPL terhadap hubungan antara profitabilitas juga telah dilakukan oleh Ali (2015) yang menunjukkan bahwa NPL berpengaruh negatif dan signifikan terhadap penyaluran kredit di sistem perbankan di Albania, begitu pula penelitian yang dilakukan oleh Devy et al. (2015) dan Bhattarai (2016) menemukan hasil yang sama bahwa NPL berpengaruh negatif dan signifikan terhadap ROA. Penelitian yang dilakukan oleh Idowu et al. (2014) dan Aktar et al. (2011) juga menunjukkan bahwa NPL berpengaruh signifikan terhadap ROA.

Pertumbuhan kredit yang diberikan lebih tinggi dari jumlah dana yang dihimpun menyebabkan peningkatan nilai LDR namun menurunnya nilai CAR (Anjani dan Purnawati 2014). Penurunan nilai CAR tersebut dikarenakan besarnya kredit yang disalurkan telah melebihi dana yang dihimpun, sehingga bank juga menggunakan modalnya untuk memenuhi permintaan kredit yang besar tersebut. Penelitian yang dilakukan oleh Krisna (2008), Yuanjuan dan Xiao (2012) serta Fitrianto dan Wisnu (2006) menemukan hasil bahwa LDR memiliki hubungan negatif dan signifikan terhadap CAR. Namun, berbeda dengan 
penelitian Shitawati (2006), Abusharba et al. (2013) bahwa LDR berpengaruh positif dan signifikan terhadap CAR serta penelitian Saraswati (2008) dan Williams (2011) bahwa LDR berpengaruh positif namun tidak signifikan terhadap CAR.

Penelitian mengenai LDR terhadap hubungan antara ROA yang dilakukan oleh Devi (2015) yang menunjukkan bahwa Hasil LDR terhadap ROA menunjukkan bahwa LDR tidak berpengaruh signifikan terhadap ROA. Sedangkan penelitian menurut Buchory (2015) menemukan hasil LDR berpengaruh negatif tetapi tidak signifikan terhadap ROA. Berbeda dengan penelitian Devy et al.(2015) dan Onuonga (2014) menemukan bahwa LDR memiliki pengaruh positif dan signifikan terhadap ROA. Penelitian yang dilakukan oleh Dhanuskodi (2014) menyatakan bahwa LDR berpengaruh positif dan tidak signifikan terhadap ROA.

Penelitian yang dilakukan oleh Agustiningrum (2013) menjelaskan bahwa CAR berpengaruh positif terhadap profitabilitas. Hal ini berarti semakin kecil risiko yang ada pada bank tersebut akan memberikan keuntungan yang besar bagi bank. Penelitian yang dilakukan oleh Al-Qudah dan Mahmoud (2013) juga menemukan hasil yang positif antara CAR dengan profitabilitas. Bank yang memiliki modal yang tinggi akan mencapai keuntungan yang tinggi karena bank tersebut lebih cermat dalam memilih sumber pembiayaan (Al-Qudah dan Mahmoud, 2013). Hal ini bertentangan dengan hasil penelitian Alper dan Adem (2011) serta Mawardi (2004) yang menyatakan bahwa capital adequacy ratio tidak memiliki pengaruh yang penting terhadap profitabilitas. Poposka et al.(2013) serta 
Jha dan Hui (2012) menyatakan bahwa CAR berpengaruh negatif terhadap ROA.

Berdasarkan uraian latar belakang dan adanya research gap dari penelitianpenelitian sebelumnya mengenai hubungan antara NPLdan LDR terhadap profitabilitas dengan CAR sebagai variabel mediasi maka penelitian ini bertujuan untuk menganalisis pengaruh NPL dan LDR terhadap CAR pada LPD di Kota Denpasar, serta untuk menganalisis pengaruh NPL, LDR dan CAR terhadap profitabilitas pada LPD di Kota Denpasar.

Berdasarkan landasan teori dan kajian empiris pada penelitian terdahulu, maka secara sistematis, kerangka konseptual dalam penelitian dapat digambarkan sebagai berikut:

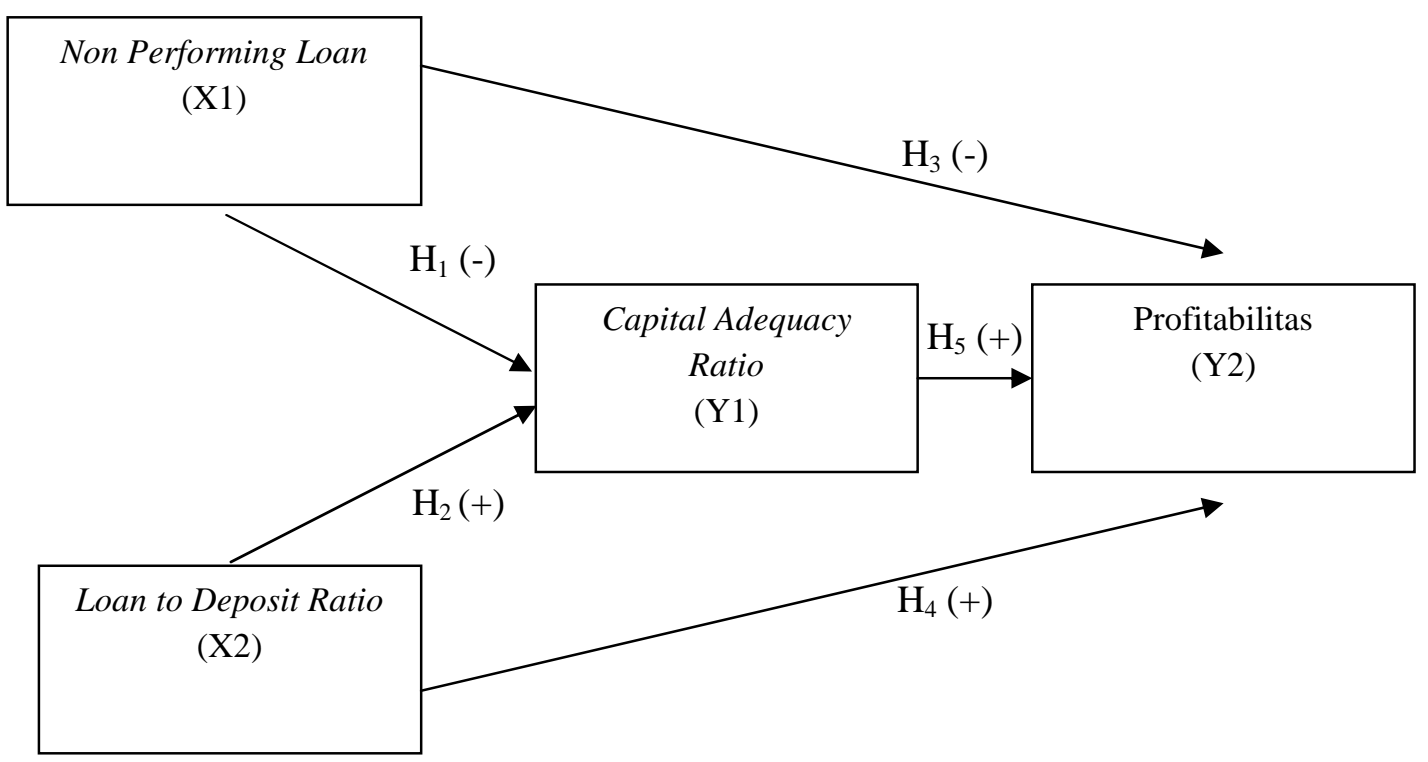

Gambar 1. Kerangka Konseptual

Sumber :Data diolah, 2018

Berdasarkan kerangka konsep pada Gambar 1, maka dapat dipaparkan rumusan hipotesis sebagai berikut:

$\mathrm{H}_{1}$ : NPL berpengaruh negatif terhadap CARpadaLPD di Kota Denpasar

$\mathrm{H}_{2}$ : LDR berpengaruh positif terhadap CAR pada LPD di Kota Denpasar. 
$\mathrm{H}_{3}$ : NPL berpengaruh negatif terhadap profitabilitas LPD di Kota Denpasar.

$\mathrm{H}_{4}$ : LDR berpengaruh positif terhadap profitabilitas LPD di Kota Denpasar.

$\mathrm{H}_{5}$ : CAR berpengaruh positif terhadap profitabilitas LPD di Kota Denpasar

\section{METODE PENELITIAN}

Penelitian ini dilakukan pada LPD di se-Kecamatan Kota Denpasar dan aktif pada LPLPD se-Kecamatan Kota Denpasar. Penelitian ini merupakan penelitian kuantitatif dengan pendekatan asosiatif (hubungan) yaitu penelitian yang bertujuan untuk mengetahui hubungan dari dua variabel atau lebih. Dalam penelitian ini menggunakan hubungan kausal, yaitu variabel bebas, variabel terikat, dan variabel mediasi.

Variabel terikat (Y2) dalam penelitian ini adalah profitabilitasyang diukur dengan proksi ROA yaitu rasio profitabilitas yang menunjukkan perbandingan antara laba setelah pajak dengan total aset bank pada LPD di Kota Denpasar. Rumus perhitungan ROA dalam penelitian ini adalah sebagai berikut:

$\mathrm{ROA}=\frac{\mathrm{L} \quad \text { S } \quad \mathrm{P}}{\mathrm{T}} \times 100 \%$

Variabel mediasi (Y1) dalam penelitian ini adalah Capital Adequacy Ratio(CAR).CAR merupakan perbandingan antara jumlah modal dengan aktiva tertimbang menurut risiko. Berdasarkan Peraturan Bank Indonesia No.15/12/PBI/2013, permodalan minimum yang harus dimiliki oleh suatu bank adalah 8 persen. CAR diukur dengan skala rasio dan besarnya dinyatakan dalam satuan persentase $(\%)$.

$\mathrm{CAR}=\frac{\mathrm{M} \quad \mathrm{I} /}{\mathrm{A}} \times 100 \%$ 
Variabel bebas dalam penelitian ini adalah Non Performing Loan $\left(\mathrm{X}_{1}\right)$ dan Loan to Deposit Ratio $\left(\mathrm{X}_{2}\right)$. NPL merupakan perbandingan antara kredit kurang lancar, diragukan dan macet dengan total kredit yang telah diberikan. NPL diukur dengan skala rasio dan besarnya dinyatakan dalam satuan persentase (\%).

$\mathrm{NPL}=\frac{\mathrm{K} \quad \mathrm{b}}{\mathrm{T} K} \times 100 \%$

LDR merupakan rasio yang digunakan untuk mengukur jumlah kredit yang diberikan dibandingkan dengan jumlah dana masyarakat dan modal sendiri yang digunakan pada LPD se-Kecamatan Kota Denpasar periode 2014-2016. LDR diukur dengan membandingkan besarnya kredit yang diberikan dengan jumlah dana yang diperoleh dari pihak ketiga (total tabungan, simpanan berjangka) dan modal inti (modal dasar, modal donasi, cadangan umum, dan laba rugi tahun berjalan) pada LPD di Kota Denpasar periode 2014-2016 dalam satuan persentase

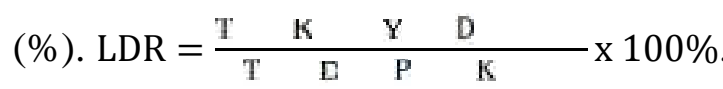

Populasi dalam penelitian ini adalah 35 LPD di Kota Denpasar.Metode penentuan sampel yang digunakan dalampenelitian iniadalah menggunakanmetode purposive sampling karenatidaksemuamemilikikriteriasesuaidenganfenomenayang diteliti.Maka penelitimenggunakankriteria khusussebagaisyaratpopulasiyakniLPDdi se-Kecamatan Kota Denpasar yang masih aktif dapatdijadikan sampelsesuaidengan tujuan penelitianyaitu berjumlah 33 LPD di se-Kecamatan Kota Denpasar.

Teknik analisis data yang digunakan untuk menguji pengaruh NPL dan LDR terhadap profitabilitas dengan CAR sebagai sebagai variabel mediasi adalah teknik analisis jalur atau path analysis. Sebelum menggunakan hasil analisis jalur 
tersebut, maka terlebih dahulu dilakukan uji asumsi klasik yaitu uji normalitas, multikolinearitas, heteroskedastisitas dan autokorelasi yang bertujuan untuk mendapat nilai parameter penduga yang sah. Nilai yang sah akan di dapat apabila uji asumsi klasik memenuhi asumsi normalitas, sedangkan pada multikolinearitas, heteroskedastisitas dan autokorelasi tidak terjadi. Adapun persamaan struktural yang digunakan dalam penelitian ini adalah sebagai berikut:

Sub Struktur 1: Y1 = $\beta 1 \mathrm{X} 1+\beta 2 \mathrm{X} 2+1$

Sub Struktur 2: Y2 $=\beta 3 \mathrm{X} 1+\beta 4 \mathrm{X} 2+\beta 5 \mathrm{Y} 1+2$

Keterangan:

$$
\begin{aligned}
& \mathrm{X} 1=\mathrm{NPL} \\
& \mathrm{X} 2=\mathrm{LDR} \\
& \mathrm{Y} 1=\mathrm{CAR} \\
& \mathrm{Y} 2=\text { Profitabilitas } \\
& \beta 1=\text { koefisien jalur } \mathrm{X} 1 \text { dengan } \mathrm{Y} 1 \\
& \beta 2=\text { koefisien jalur } \mathrm{X} 2 \text { dengan } \mathrm{Y} 1 \\
& \beta 3=\text { koefisien jalur } \mathrm{X} 1 \text { dengan } \mathrm{Y} 2 \\
& \beta 4=\text { koefisien jalur } \mathrm{X} 2 \text { dengan } \mathrm{Y} 2 \\
& \beta 5=\text { koefisien jalur } \mathrm{Y} 1 \text { dengan } \mathrm{Y} 2
\end{aligned}
$$

\section{HASIL DAN PEMBAHASAN}

Hasil statistik nilai minimum, nilai maksimum, nilai rata-rata, dan standar deviasi yang dapat dilihat pada Tabel 1 .

Tabel 1.

Hasil Statistik Deskriptif Variabel Penelitian

\begin{tabular}{cccccc}
\hline & N & Minimum & Maximum & Mean & Std. Deviation \\
\hline NPL & 99 & 0,00 & 26,10 & 8,3825 & 6,00859 \\
LDR & 99 & 48,99 & 100,24 & 79,0125 & 11,82265 \\
CAR & 99 & 2,69 & 11,49 & 6,2488 & 1,89457 \\
ROA & 99 & 1,46 & 7,21 & 4,4460 & 1,34625 \\
Valid N (listwise) & 99 & & & & \\
\hline Sumber: Data diolah, 2018 & & &
\end{tabular}


Berdasarkan hasil uji statistik deskriptif pada Tabel 1 didapatkan informasi bahwa non performing loan paling rendah (minimum) adalah sebesar 0,00 persen dimiliki oleh LPD Denpasar pada tahun 2016. Nilai non performing loan yang paling tinggi (maksimum) adalah sebesar 26,10 persen yang dimiliki oleh LPD Peraupan pada tahun 2016. Non performing loan memiliki nilai rata-rata sebesar 8,3825 persen dengan nilai standar deviasi sebesar 6,008 persen. Ini berarti bahwa terjadi perbedaan nilai non performing loan yang diteliti terhadap nilai rataratanya sebesar 6,008 persen, yang artinya bahwa nilai mean lebih besar dari pada standar deviasi, sehingga mengindikasikan bahwa hasil yang cukup baik.

Loan to deposit ratio paling rendah (minimum) adalah sebesar 48,99 persen dimiliki oleh LPD Lap-lap pada tahun 2015 dan loan to deposit ratio yang paling tinggi (maksimum) adalah sebesar 100,24 persen yang dimiliki oleh LPD Cengkilung pada tahun 2015. Loan to deposit ratio memiliki nilai rata-rata sebesar 79,012 persen dengan nilai standar deviasi sebesar 11,822 persen. Ini berarti bahwa terjadi perbedaan nilai loan to deposit ratio yang diteliti terhadap nilai rata-ratanya sebesar 11,822 persen, yang artinya bahwa nilai mean lebih besar dari pada standar deviasi, sehingga mengindikasikan bahwa hasil yang cukup baik.

Capital adequacy ratio paling rendah (minimum) adalah sebesar 2,69 persen dimiliki oleh LPD Peguyangan pada tahun 2014 dan capital adequacy ratio yang paling tinggi (maksimum) adalah sebesar 11,49 persen yang dimiliki oleh LPD Poh Manis pada tahun 2016. Capital adequacy ratio memiliki nilai ratarata sebesar 6,248 persen dengan nilai standar deviasi sebesar 3,894 persen. Ini 
berarti bahwa terjadi perbedaan nilai capital adequacy ratio yang diteliti terhadap nilai rata-ratanya sebesar 6,248 persen, yang artinya bahwa nilai mean lebih besar dari pada standar deviasi, sehingga mengindikasikan bahwa hasil yang cukup baik.

Profitabilitaspaling rendah (minimum) adalah sebesar 1,46 persen dimiliki oleh LPD Oongan pada tahun 2016. Nilai profitabilitasyang paling tinggi (maksimum) adalah sebesar 7,21 persen yang dimiliki oleh LPD Poh Manis pada tahun 2014. Profitabilitasmemiliki nilai rata-rata sebesar 4,446 persen dengan nilai standar deviasi sebesar 1,346 persen. Ini berarti bahwa terjadi perbedaan profitabilitasyang diteliti terhadap nilai rata-ratanya sebesar 1,346 persen, yang artinya bahwa nilai mean lebih besar dari pada standar deviasi, sehingga mengindikasikan bahwa hasil yang cukup baik.

Analisis regresi sangat memerlukan bagian asumsi agar model dapat digunakan sebagai alat prediksi baik, hasil rangkuman uji asumsi klasik dalam penelitian ini dapat dilihat pada Tabel 2.

Tabel 2.

Rangkuman Hasil Uji Asumsi Klasik

\begin{tabular}{|c|c|c|c|c|c|c|c|}
\hline \multirow[b]{2}{*}{ Struktur } & \multirow[b]{2}{*}{ Variabel } & \multirow{2}{*}{$\begin{array}{l}\text { Normalitas } \\
\text { Asymp.Sig. } \\
\text { (2-tailed) }\end{array}$} & \multicolumn{2}{|c|}{ Multikolinieritas } & \multicolumn{2}{|c|}{ Autokorelasi } & \multirow{2}{*}{$\begin{array}{c}\text { Heteroskedastisitas } \\
\text { (Signifikansi) }\end{array}$} \\
\hline & & & Tolerance & VIF & Du & Dw & \\
\hline \multirow{2}{*}{1} & $\begin{array}{l}\text { NPL } \\
\left(\mathrm{X}_{1}\right)\end{array}$ & \multirow{2}{*}{0,899} & 0,935 & 1,069 & \multirow{2}{*}{1,714} & \multirow{2}{*}{1,799} & 0,597 \\
\hline & $\begin{array}{c}\text { LDR } \\
\left(\mathrm{X}_{2}\right)\end{array}$ & & 0,935 & 1,069 & & & 0,599 \\
\hline \multirow{3}{*}{2} & $\begin{array}{l}\text { NPL } \\
\left(X_{1}\right)\end{array}$ & \multirow{3}{*}{0,780} & 0,909 & 1,1 & \multirow{3}{*}{1,7355} & \multirow{3}{*}{1,959} & 0,522 \\
\hline & $\begin{array}{l}\text { LDR } \\
\left(\mathrm{X}_{2}\right)\end{array}$ & & 0,886 & 1,129 & & & 0,284 \\
\hline & $\begin{array}{c}\text { CAR } \\
\left(\mathrm{Y}_{1}\right)\end{array}$ & & 0,899 & 1,113 & & & 0,599 \\
\hline
\end{tabular}

Sumber: Data diolah, 2018

Hasil pengujian pada persamaan struktur 1 dan 2 dalam Tabel 2 
menunjukkan bahwa nilai Asymp. Sig (2-tailed) struktur 1 sebesar 0,899 dan nilai Asymp. Sig (2-tailed) struktur 2 sebesar 0,780. Nilai tersebut lebih besar dari level of significant, yaitu 5\% $(0,05)$. Jadi dapat disimpulkan bahwa residual berdistribusi normal.

Berdasarkan Tabel 2 dapat dilihat bahwa nilai VIF dan Tolerance, dimana diperlihatkan bahwa tidak terdapat nilai Tolerance yang kurang dari 0,1 (10 persen) ataupun nilai VIF yang lebih tinggi dari 10. Oleh karena itu berdasarkan nilai Tolerance dan VIF pada model analisis tersebut tidak ditemukan adanya gejala multikolinearitas.

Tabel 2 juga menunjukkan bahwa besarnya nilai Durbin Watson untuk persamaan struktur 1 sebesar 1,828. Nilai D-W menurut tabel dengan $\mathrm{n}=99$ dan $\mathrm{k}$ $=2$, maka didapat nilai $\mathrm{dl}=1,6317$ dan nilai $\mathrm{du}=1,714$. Oleh karena nilai $\mathrm{du}<\mathrm{dw}<(4-\mathrm{du})$ yaitu $(1,714<1,799<2,286)$, maka dapat disimpulkan tidak terdapat autokorelasi antar residual pada persamaan struktur 1. Nilai Durbin Watson untuk persamaan struktur 2 sebesar 1,959. Nilai D-W menurut tabel dengan $\mathrm{n}=99 \mathrm{dan} \mathrm{k}$ $=3$, maka didapat nilai $\mathrm{dl}=1,6108$ dan nilai $\mathrm{du}=1,7355$. Oleh karena nilai $\mathrm{du}<\mathrm{dw}<(4-\mathrm{du})$ yaitu $(1,7355<1,959<2,2645)$, maka dapat disimpulkan tidak terdapat autokorelasi antar residual pada persamaan struktur 2 .

Apabila dilihat dari hasil uji heteroskedastisitas menunjukkan bahwa nilai signifikansi pada persamaan struktur 1 yaitu NPL $\left(\mathrm{X}_{1}\right)$ sebesar 0,597 dan LDR $\left(\mathrm{X}_{2}\right)$ sebesar 0,599 . Nilai signifikansi pada persamaan struktur 2 yaitu NPL $\left(\mathrm{X}_{1}\right)$ sebesar 0,522, LDR $\left(\mathrm{X}_{2}\right)$ sebesar 0,284, dan CAR sebesar 0,599. Hasil uji tersebut memiliki nilai yang lebih besar dari $\alpha=0.05$, sehingga dapat disimpulkan bahwa 
pada persamaan struktur 1 dan 2 tidak terjadi heteroskedastisitas. Oleh karena seluruh uji asumsi klasik dalam penelitian ini sudah memenuhi syarat, maka analisis lebih lanjut layak untuk dilakukan.

Pengujian data dalam penelitian ini menggunakan teknik analisis jalur (Path Analysis), dimana analisis jalur adalah perluasan dari analisis regresi linear berganda untuk menguji hubungan kausalitas antara 2 atau lebih variabel. Perhitungan koefisien path dilakukan dengan analisis regresi melalui software SPSS 18.0 for Windows, dengan hasil pada Tabel 3.

Tabel 3.

Hasil Analisis Jalur Struktur 1

\begin{tabular}{|c|c|c|c|c|c|c|}
\hline & \multirow[t]{2}{*}{ Model } & Unstanda & Coefficients & \multirow{2}{*}{$\begin{array}{c}\text { Standardized } \\
\text { Coefficients } \\
\text { Beta }\end{array}$} & \multirow[t]{2}{*}{$\mathbf{t}$} & \multirow[t]{2}{*}{ Sig. } \\
\hline & & B & Std. Error & & & \\
\hline \multirow[t]{3}{*}{1} & (Constant) & 8,741 & 1,370 & & 6,379 & 0,000 \\
\hline & NPL & 0,053 & 0,032 & 0,167 & 1,674 & 0,097 \\
\hline & LDR & $-0,037$ & 0,016 & $-0,232$ & $-2,317$ & 0,023 \\
\hline
\end{tabular}

Sumber: Data diolah, 2018

Berdasarkan hasil analisis jalur substruktur 1 seperti yang disajikan pada Tabel 3, maka persamaan strukturalnya adalah sebagai berikut :

$$
\mathrm{Y} 1=0,167 \mathrm{X} 1-0,232 \mathrm{X} 2+\mathrm{e}_{1}
$$

Berdasarkan hasil analisis pengaruh Non performing loan terhadap Capital adequacy ratio diperoleh nilai Signifikansi sebesar 0,097 dengan nilai koefisien beta 0,167 . Nilai signifikansi $0,097>0,05$ mengindikasikan bahwa $\mathrm{H}_{0}$ diterima dan $\mathrm{H}_{1}$ ditolak. Hasil ini mempunyai arti bahwa Non performing loan tidak berpengaruh terhadap Capital adequacy ratio. Kemudian hasil analisis pengaruh Loan to deposit ratio terhadap Capital adequacy ratio diperoleh nilai Signifikansi sebesar 0,023 dengan nilai koefisien beta $-0,232$. Nilai Signifikansi 0,023 $<0,05$ 
mengindikasikan bahwa $\mathrm{H}_{0}$ diterima dan $\mathrm{H}_{2}$ ditolak. Hasil ini mempunyai arti bahwa Loan to deposit ratioberpengaruh negatif dan signifikan terhadap Capital adequacy ratio.

Tabel 4.

Hasil Analisis Jalur Struktur 2

\begin{tabular}{|c|c|c|c|c|c|c|}
\hline & \multirow[t]{2}{*}{ Model } & \multicolumn{2}{|c|}{$\begin{array}{c}\text { Unstandardized } \\
\text { Coefficients }\end{array}$} & \multirow{2}{*}{$\begin{array}{c}\begin{array}{c}\text { Standardized } \\
\text { Coefficients } \\
\text { Beta }\end{array} \\
\end{array}$} & \multirow[t]{2}{*}{$\mathbf{t}$} & \multirow[t]{2}{*}{ Sig. } \\
\hline & & B & Std. Error & & & \\
\hline \multirow[t]{4}{*}{1} & (Constant) & $-0,127$ & 0,970 & & $-0,131$ & 0,896 \\
\hline & NPL & $-0,038$ & 0,019 & $-0,172$ & $-2,025$ & 0,046 \\
\hline & LDR & 0,026 & 0,010 & 0,229 & 2,668 & 0,009 \\
\hline & CAR & 0,454 & 0,061 & 0,639 & 7,491 & 0,000 \\
\hline
\end{tabular}

Sumber: Data diolah, 2018

Berdasarkan hasil analisis jalur substruktur 2 seperti yang disajikan pada Tabel 4, maka persamaan strukturalnya adalah sebagai berikut :

$$
\mathrm{Y} 2=-0,172 \mathrm{X} 1+0,229 \mathrm{X} 2+0,639 \mathrm{Y} 1+\mathrm{e}_{2}
$$

Berdasarkan hasil analisis pengaruh Non performing loan terhadap Profitabilitas diperoleh nilai signifikansi sebesar 0,046 dengan nilai koefisien beta $-0,172$. Nilai signifikansi $0,046<0,05$ mengindikasikan bahwa $\mathrm{H}_{0}$ ditolak dan $\mathrm{H}_{3}$ diterima. Hasil ini mempunyai arti bahwa Non performing loanberpengaruh negatif dan signifikan terhadap Profitabilitas. Kemudian hasil analisis pengaruh Loan to deposit ratio terhadap Profitabilitas diperoleh nilai signifikansi sebesar 0,009 dengan nilai koefisien beta 0,229. Nilai signifikansi $0,009<0,05$ mengindikasikan bahwa $\mathrm{H}_{0}$ ditolak dan $\mathrm{H}_{4}$ diterima. Hasil ini mempunyai arti bahwa Loan to deposit ratioberpengaruh positif dan signifikan terhadap Profitabilitas. Selanjutnya, hasil analisis pengaruh Capital adequacy ratio terhadap Profitabilitas diperoleh nilai signifikansi sebesar 0,000 dengan nilai koefisien beta 0,639 . Nilai signifikansi $0,000<0,05$ mengindikasikan bahwa 
$\mathrm{H}_{0}$ ditolak dan $\mathrm{H}_{5}$ diterima. Hasil ini mempunyai arti bahwa Capital adequacy ratioberpengaruh positif dan signifikan terhadap Profitabilitas.

Berdasarkan perhitungan terhadap substruktur 1 dan 2, maka dapat diketahui besarnya pengaruh langsung, pengaruh tidak langsung dan pengaruh total antar variabel. Perhitungan pengaruh antar variabel dapat dilihat pada Tabel 5.

Tabel 5.

Pengaruh Langsung dan Pengaruh Tidak Langsung serta Pengaruh Total Variabel Penelitian

\begin{tabular}{ccc}
\hline \multicolumn{2}{c}{ Pengaruh Variabel } & Pengaruh Langsung \\
\hline $\mathrm{X}_{1} \rightarrow \mathrm{Y}_{1}$ & $\mathrm{NPL} \rightarrow \mathrm{CAR}$ & 0,167 \\
$\mathrm{X}_{1} \rightarrow \mathrm{Y}_{2}$ & $\mathrm{NPL} \rightarrow \mathrm{ROA}$ & $-0,172$ \\
$\mathrm{X}_{1} \rightarrow \mathrm{Y}_{1} \rightarrow \mathrm{Y}_{2}$ & $\mathrm{NPL} \rightarrow \mathrm{CAR} \rightarrow \mathrm{ROA}$ & $(0,167 \times 0,639)=0,106$ \\
$\mathrm{X}_{2} \rightarrow \mathrm{Y}_{2}$ & $\mathrm{LDR} \rightarrow \mathrm{ROA}$ & 0,229 \\
$\mathrm{X}_{2} \rightarrow \mathrm{Y}_{1} \rightarrow \mathrm{Y}_{2}$ & $\mathrm{LDR} \rightarrow \mathrm{CAR} \rightarrow \mathrm{ROA}$ & $(-0,232 \times 0,639)=-0,148$ \\
$\mathrm{X}_{2} \rightarrow \mathrm{Y}_{1}$ & $\mathrm{LDR} \rightarrow \mathrm{CAR}$ & $-0,232$ \\
$\mathrm{Y}_{1} \rightarrow \mathrm{Y}_{2}$ & $\mathrm{CAR} \rightarrow \mathrm{ROA}$ & 0,639 \\
\hline
\end{tabular}

Sumber : Data diolah, 2018

Berdasarkan model substruktur 1 dan substruktur 2, maka dapat disusun model diagram jalur akhir. Sebelum menyusun model diagram jalur akhir, terlebih dahulu dihitung nilai standar eror sebagai berikut :

$$
\begin{aligned}
& \mathrm{Pe}_{\mathrm{i}}=\sqrt{1-\mathrm{R}_{\mathrm{i}}{ }^{2}} \ldots \ldots \ldots \ldots \ldots \ldots \ldots \ldots \ldots \ldots \ldots \ldots \\
& \mathrm{Pe}_{1}=\sqrt{1-0,101}=\sqrt{0,899}=0,948 \\
& \mathrm{Pe}_{2}=\sqrt{1-0,380}=\sqrt{0,620}=0,787 .
\end{aligned}
$$

Berdasarkan perhitungan pengaruh error (Pei), didapatkan hasil pengaruh error $\left(\mathrm{Pe}_{1}\right)$ sebesar 0,948 dan pengaruh error $\left(\mathrm{Pe}_{2}\right)$ sebesar 0,787. Hasil koefisien determinasi total adalah sebagai berikut :

$$
\begin{aligned}
\mathrm{R}_{\mathrm{m}}^{2} & =1-\left(\mathrm{Pe}_{1}\right)^{2}\left(\mathrm{Pe}_{2}\right)^{2} \ldots \ldots \ldots \ldots \ldots \ldots \\
& =1-(0,948)^{2}(0,787)^{2}=0,658
\end{aligned}
$$


Nilai determinasi total sebesar 0,658 mempunyai arti bahwa sebesar 65,8 persen variasi Profitabilitasdipengaruhi oleh variasi Non performing loan, Loan to deposit ratio dan Capital adequacy ratio, sedangkan sisanya sebesar 34,2 persen djelaskan oleh faktor lain yang tidak dimasukkan ke dalam model.Hasil nilai dari perhitungan koefisien jalur secara rinci dapat dilihat pada Gambar 2.

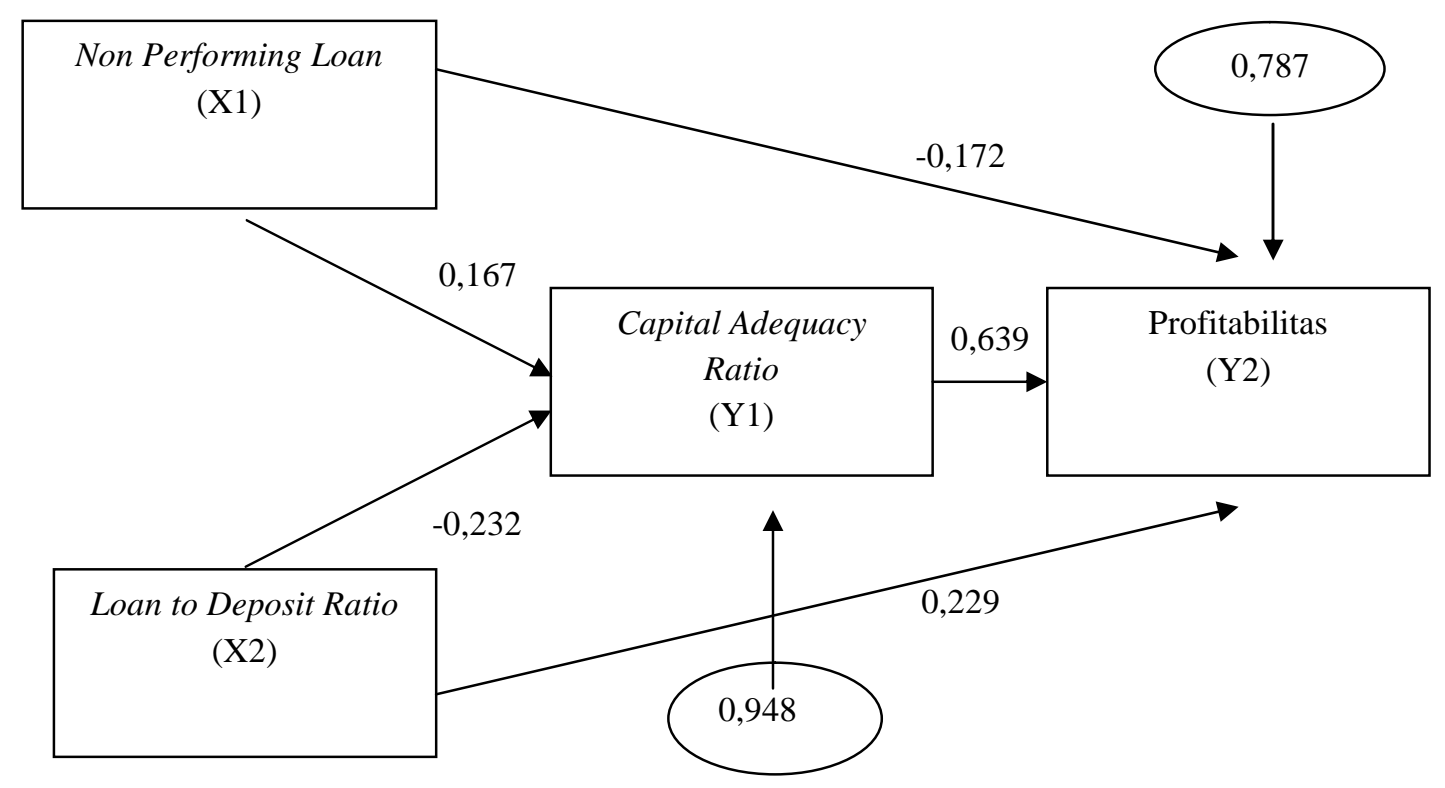

Gambar 2. Model Diagram Jalur Akhir

Sumber : Data primer diolah, 2018

\section{Pengaruh Non Performing Loan terhadap Capital Adequacy Ratio}

Hasil analisis regresi menunjukkan bahwa non performing loansecara statistik tidak berpengaruh signifikan pada capital adequacy ratio Lembaga Perkreditan Desa di Kota Denpasar ( $\mathrm{H}_{1}$ ditolak). Secara teori Non performing loan suatu bank jika mengalami peningkatan maka akan mempengaruhi permodalan bank karena bank harus menyediakan dana untuk memenuhi PPAP yang terbentuk (Pauzi, 2010). Modal bank yang seharusnya dapat digunakan untuk investasi 
lainnya menjadi berkurang akibat dari adanya pembentukan PPAP.

Diperolehnya hasil NPL tidak berpengaruh terhadap CAR ini, disebabkan oleh kenaikan rasio NPL yang mengandung arti naiknya kredit bermasalah (kredit kurang lancar, diragukan dan macet) yang lebih besar dari kenaikan jumlah kredit. Hal ini mengingat NPL merupakan gambaran risiko kredit yang ditanggung oleh pihak bank atas total kredit yang disalurkannya. NPL yang tinggi akan menyebabkan kerugian yang diakibatkan tingkat pengembalian kredit yang rendah. Seperti terjadinya penurunan pada pendapatan yang akan diterima bank dari bunga atas kredit yang disalurkan. Akan tetapi tidak selalu dengan timbulnya kredit bermasalah akan memiliki risiko yang besar pada pendapatan operasional bank secara keseluruhan, ini disebabkan pendapatan operasional bank bukan hanya berasal dari pendapatan bunga kredit meski pendapatan dari sektor bunga kredit merupakan pendapatan terbesar bank, namun pendapatan operasional bank juga dapat berasal dari pendapatan aktiva produktif lainnya. Sehingga NPL tidak berpengaruh terhadap CAR bank (Yuliani dkk., 2015).

Hasil penelitian ini didukung oleh hasil penelitian yang dilakukan oleh Anjani dan Purnawati (2014) yang memperoleh hasil bahwa non performing loantidak berpengaruh signifikan terhadap capital adequacy ratio. Hasil penelitian ini tidak sejalan temuan Margaretha dan Diana (2011), Tracey (2011), serta Buyuksalvarci dan Hasan (2011) yang menyatakan bahwa NPL memiliki pengaruh negatif signifikan terhadap CAR. 


\section{Pengaruh Loan to Deposit Ratio terhadap Capital Adequacy Ratio}

Hasil analisis regresi menunjukkan bahwa loan to deposit ratiosecara statistik berpengaruh negatif dan signifikan pada capital adequacy ratio Lembaga Perkreditan Desa di Kota Denpasar $\left(\mathrm{H}_{2}\right.$ ditolak). Hal ini mengindikasikan bahwa semakin tinggi loan to deposit ratio, maka akan menyebabkancapital adequacy ratio semakin menurun.Hubungan negatif yang diperoleh dalam penelitian ini mengandung arti bahwa LDR berbanding terbalik dengan CAR. Jika LDR naik maka CAR akan mengalami penurunan dan demikian sebaliknya jika LDR turun maka CAR akanmengalami kenaikan. Dengan semakin tingginya LDR sebagai dampak dari pertumbuhan jumlah penyaluran kredit lebih besar dari pertumbuhan jumlah dana diterima, maka akan membuat kondisi likuiditas bank semakin berisiko. Karena terbatasnya jumlah dana yang dimiliki bank dalam memenuhi seluruh kewajiban jangka pendeknya. Kondisi tersebut akan dapat mengakibatkan hilangnya kepercayaan masyarakat pada suatu bank. Untuk itu, dalam upaya menjaga kepercayaan masyarakat pada bank diperlukan penyediaan jumlah dana yang besar yang kemungkinan diambilkan dari modal bank guna penyediaan likuiditasnya. Disamping itu, akibat dari penyaluran kredit yang besar maka akan membuat nilai Aktiva Tertimbang Menurut Risiko (ATMR) akan semakin besar, sehingga kemampuan modal bank dalam menanggulangi kemungkinan terjadinya risiko yang diakibatkan oleh kegiatan operasional bank akan semakin rendah. Oleh karena itu, meningkatnya LDR akan menurunkan CAR bank (Yuliani, dkk 2015). 
Hasil penelitian ini sejalan dengan penelitian yang dilakukan oleh Anjani dan Purnawati (2014) yang menyatakan bahwa pertumbuhan kredit yang diberikan lebih tinggi dari jumlah dana yang dihimpun menyebabkan peningkatan nilai loan to deposit ratio namun menurunnya nilai capital adequacy ratio. Penurunan nilai CAR tersebut dikarenakan besarnya kredit yang disalurkan telah melebihi dana yang dihimpun, sehingga bank juga menggunakan modalnya untuk memenuhi permintaan kredit yang besar tersebut. Hasil penelitian ini tidak mendukung penelitian yang dilakukan oleh Shitawati (2006), Abusharba et al. (2013) serta Saraswati (2008) dan Williams (2011) yang menyatakan bahwa LDR berpengaruh positif terhadap CAR.

\section{Pengaruh Non Performing Loan terhadap Profitabilitas}

Hasil analisis regresi menunjukkan bahwa non performing loansecara statistik berpengaruh negatif dan signifikan pada profitabilitas Lembaga Perkreditan Desa di Kota Denpasar $\left(\mathrm{H}_{3}\right.$ diterima). Hal ini berarti bahwa semakin rendah risiko kredit (NPL) maka akan meningkatkan profitabilitas, dimana ketika rendahnya NPL maka kredit yang disalurkan berjalan dengan baik sehingga frekuensi perputaran dana lebih tinggi dalam menghasilkan laba melalui kredit. Semakin rendah tingkat NPL maka profitabilitas (ROA) yang diperoleh oleh bank tersebut akan semakin meningkat. NPL merupakan pinjaman yang mengalami kesulitan pelunasan atau disebut sebagai kredit macet. NPL merupakan perbandingan antara total kredit bemasalah dengan total kredit yang diberikan bank kepada debitur. Semakin tinggi rasio NPL maka akan semakin buruk kualitas kredit bank yang menyebabkan jumlah kredit bermasalah semakin besar 
sehingga bank harus menanggung kerugian dalam kegiatan operasionalnya yang berpengaruh terhadap penurunan laba yang diperoleh bank (Putri, 2013).

Hasil penelitian ini didukung dengan penelitian yang dilakukan oleh Ali (2015) yang menunjukkan bahwa NPL berpengaruh negatif dan signifikan terhadap penyaluran kredit terhadap ROA. Penelitian yang dilakukan oleh Brunilda (2015) juga menunjukkan bahwa NPL berpengaruh negatif terhadap profitabilitas. Penelitian yang dilakukan oleh Devy et al. (2015) dan Bhattarai (2016) menemukan hasil yang sama bahwa NPL berpengaruh negatif dan signifikan terhadap ROA. Penelitian yang dilakukan oleh Sokol (2016) juga menemukan hasil bahwa NPL berpengaruh negatif terhadap ROA.

\section{Pengaruh Loan to Deposit Ratio terhadap Profitabilitas}

Hasil analisis regresi menunjukkan bahwa loan to deposit ratiosecara statistik berpengaruh positif dan signifikan pada profitabilitas Lembaga Perkreditan Desa di Kota Denpasar ( $\mathrm{H}_{4}$ diterima). Hal ini berarti bahwa semakin tinggi LDR maka profitabilitas (ROA) akan semakin meningkat, dimana ketika tingginya LDR maka dana pihak ketiga yang disalurkan ke dalam bentuk kredit akan semakin besar sehingga kemampuan bank dalam menghasilkan laba melalui ekspansi kredit akan semakin tinggi. LDR merupakan rasio yang mengukur komposisi jumlah kredit yang diberikan dibandingkan dengan jumlah dana masyarakat dan modal sendiri yang digunakan (Kasmir, 2008:225). Berdasarkan Peraturan Bank Indonesia No. 15/7/PBI/2013 standar LDR yaitu 78 persen - 92 persen. Jika angka rasio LDR berada dibawah atau kurang dari 78 persen maka dapat diartikan bahwa bank tersebut tidak dapat menyalurkan kembali dengan 
baik seluruh dana yang telah dihimpun. Jika angka rasio LDR berada diatas atau lebih dari 92 persen, maka total kredit yang disalurkan oleh bank tersebut melebihi dana yang dihimpun. Tinggi rendahnya tingkat LDR suatu LPD akan mempengaruhi profitabilitas LPD tersebut.

Hasil penelitian ini sesuai dengan penelitian yang dilakukan oleh Devy et al (2015) dan Onuonga (2014) yang menyatakan bahwa LDR memiliki pengaruh positif dan signifikan terhadap ROA. Penelitian ini juga didukung oelh penelitian yang dilakukan Abdelkarim (2013) dan Suryanto (2017) menemukan bahwa LDR memiliki pengaruh positif dan signifikan terhadap ROA.

\section{Pengaruh Capital Adequacy Ratio terhadap Profitabilitas}

Hasil analisis regresi menunjukkan bahwa capital adequacy ratiosecara statistik berpengaruh positif dan signifikan pada profitabilitas Lembaga Perkreditan Desa di Kota Denpasar $\left(\mathrm{H}_{5}\right.$ diterima). Hal ini berarti bahwa semakin tinggi capital adequacy ratio maka profitabilitas (ROA) akan semakin meningkat. CAR merupakan rasio kewajiban pemenuhan modal minimum yang harus dimiliki oleh LPD atau merupakan kemampuan LPD dalam permodalan yang ada untuk menutup kemungkinan kerugian di dalam sistem perkreditan. Semakin tinggi tingkat permodalan maka semakin tinggi tingkat profitabilitas LPD, begitu pula sebaliknya semakin rendah tingkat permodalan maka semakin rendah tingkat profitabilitasnya.

Hasil penelitian ini sesuai dengan penelitian yang dilakukan oleh Agustiningrum (2013) yang menyatakan bahwa CAR berpengaruh positif terhadap profitabilitas. Hal ini berarti semakin kecil risiko yang ada pada bank 
tersebut akan memberikan keuntungan yang besar bagi bank. Penelitian ini juga didukung oleh Al-Qudah dan Mahmoud (2013) yang menemukan hasil yang positif antara CAR dengan profitabilitas.

\section{Implikasi Penelitian}

Implikasi dari hasil penelitian ini mencakup dua hal, yaitu implikasi teoritis dan praktis. Implikasi teoritis penelitian ini diharapkan dapat memberikan kontribusi mengenai pengaruh NPL dan LDR terhadap profitabilitas dengan CARsebagai variabel mediasi. Hasil uji hipotesis dalam penelitian ini ditemukan bahwa NPL tidak berpengaruh terdadap CAR dan berpengaruh negatif pada profitabilitas.LPD yang memiliki tingkat kredit bermasalah yang tinggi maka kualitas aset yang dimiliki LPD tersebut semakin buruk, maka hal tersebut akan memberikan dampak negatif pada profitabilitas yang diperoleh.

Penelitian ini juga memberikan implikasi praktis bagi LPD sebagai pertimbangan maupun pengetahuan mengenai profitabilitas serta faktor-faktor yang memengaruhinya. LPD dalam upaya meningkatkan profitabilitas dapat melihat NPL, LDR, dan CARyang dimiliki, karena hal tersebut dapat mempengaruhi profitabilitas yang semakin meningkat.

\section{SIMPULAN DAN SARAN}

Simpulan yang dapat diberikan berdasarkan hasil penelitian yang dilakukan yaitu Non performing loantidak berpengaruh signifikan pada capital adequacy ratio, Loan to deposit ratioberpengaruh negatif dan signifikan pada capital adequacy ratio, Non performing loanberpengaruh negatif dan signifikan pada profitabilitas, Loan to deposit ratioberpengaruh positif dan signifikan pada 
profitabilitas, dan Capital adequacy ratioberpengaruh positif dan signifikan pada profitabilitas Lembaga Perkreditan Desa di Kota Denpasar.

Berdasarkan hasil analisis penelitian, pembahasan dan kesimpulan terdapat beberapa saran yang dapat dipergunakan sebagai bahan pertimbangan dalam menentukan kebijakan terkait faktor-faktor yang mempengaruhi Profitabilitas pada Lembaga Perkreditan Desa (LPD) di Kota Denpasar dimasa mendatang, antara lain profitabilitas dalam hal ini adalah Return On Asset (ROA). Rasio ini sangat penting bagi perusahaan karena menggambarkan kemampuan perusahaan dalam menghasilkan laba dengan menggunakan seluruh asset yang ada. Oleh sebab itu, pihak manajemen perusahaan diharapkan lebih berupaya dan meningkatkan lagi rasio Return On Asset (ROA) yaitu dengan cara meningkatkan volume penjualan, melakukan penghematan biaya operasional seperti mengurangi biaya-biaya eksternal terutama biaya kantor se-efektif mungkin, dan mengurangi atau mempertahankan aktiva (asset) yang dimiliki perusahaan serta lebih memperhatikan faktor NPL, LDR dan CAR yang dapat mempengaruhi tingkat keuntungan bagi perusahaan. Dengan demikian, tingkat profitabilitas dalam rasio ROA dapat meningkat.

Penelitian selanjutnya dapat mempertimbangkan untuk menggunakan ukuran profitabilitas lainnya atau objek penelitian selain Lembaga Perkreditan Desa (LPD) di Kota Denpasar.

\section{REFERENSI}

Abdelkarim, Almumani Mohammad. (2013). Impact of Managerial Factors on Commercial Bank Profitability: Empirical Evidence from Jordan. International Journal of Academic Research Accounting, Finance and Management Sciences. Vol. 3 (3) pp. 298-310. 
Abusharba, Mohammed. T, Iwan Triyuwono, Munawar Ismail dan Aulia F. Rahman. (2013). Determinants of Capital Adequacy Ratio (CAR) in Indonesian Islamic Commercial Banks. Global Review of Accounting and Finance, 4(1): h: 159-170.

Agustiningrum, Rizki. (2013). Analisis Pengaruh Car, Npl, Dan Ldr Terhadap Profitabilitas Pada Perusahaan Perbankan. E-Jurnal Manajemen Universitas Udayana, 2(8): h: 885-902.

Alper, Deger and AdemAnbar.(2011). Bank Specific And Macroeconomic Determinants Of Commercial Bank Profitability: Empirical Evidence From Turkey. Business and Economics Research Journal,2(2): pp: 139-152.

Al-Qudah, Ali Mustafa and Mahmoud Ali Jaradat.(2013) The Impact of Macroeconomic Variables and Banks Characteristics on Jordanian Islamic Banks Profitability: Empirical Evidence. International Business Research, 6(10): pp: 153-162.

Anjani, Dewa Ayu dan Ni Ketut Purnawati. (2014). Pengaruh non performing loan (NPL), Likuiditas dan Rentabilitas Terhadap Rasio Kecukupan Modal. E- Jurnal Manajemen Universitas Udayana, 3 (4): h: 1140-1154.

Bhattarai,. Yuga Raj. (2016). Effect of Non Performing Loan on the Profitability of Commercial Banks in Nepal. The International Journal Of Business \& Management. Vol.4 (6) .pp.435-442.ISSN 2321-8916

Buchory Achmad Herry. (2015). Banking Intermediation, Operational Effeciency And Risk In The Banking Profitability. International Journal of Business, Economics and Law, Vol 7, Issue 2 (Aug.). ISSN 2289-1552, pp. 57-63

Buyuksalvarci, Ahmet and Hasan Abdioglu. (2011). Determinants of Capital Adequacy Ratio in Turkish Banks: A panel data analysis. African Journal of Business Management, 5(27), pp:11199-11209.

Dhanuskodi, Rengasamy. (2014). Impact of Loan Deposit Ratio (LDR) on Profitability: Panel Evidence from Commercial Banks in Malaysia. Proceedings of the Third International Confrence on Global Business, Economics, Finance and Social Sciences (GB14Mumbai Conference) Mumbai, India. ISBN: 978-1-941505-21-2

Fitrianto, Hendra dan Wisnu Mawardi. (2006). Analisis Pengaruh Kualitas Aset, Likuiditas, Rentabilitas, dan Efisiensi Terhadap Rasio Kecukupan Modal Perbankan yang terdaftar di Bursa Efek Jakarta. Jurnal Studi Manajemen dan organisasi, 3(1): h:1-11.

Idroes, Ferry N. (2008). Manajemen Risiko Perbankan, Pemahaman Penekatan 3 Pilar Kesepakatan Basel II Terkait Aplikasi Regulasi dan Pelaksanaannya di Indonesia. Jakarta: PT. Raja Grafindo Persada 
Jha, Suvita and Xiaofeng Hui. (2012). A Comparison of Financial Performance of Commercial Banks: A Case Study of Nepal. African Journal of Business Management, 6(25), pp: 7601-7611.

Kasmir.(2010). Manajemen Perbankan. Edisi Revisi 9. Jakarta: Rajawali Pers.

Kasmir. (2011). Analisis Laporan Keuangan. Jakarta : PT. Raja Grafindo Persada.

Krisna, Yansen. (2008). Faktor-Faktor yang Mempengaruhi Capital Adequacy Ratio (Studi Pada Bank-bank Umum di Indonesia Periode Tahun 20032006). Program Studi Magister Manajemen, Program Pasca Sarjana Universitas Diponegoro, Semarang.

Margaretha, Farah dan Diana Setiyaningrum. (2011). Pengaruh Resiko, Kualitas Manajemen, Ukuran dan Likuiditas terhadap Capital Adequacy Ratio BankBank yang Terdaftar di Bursa Efek Indonesia. Jurnal Akuntasi Keuangan, 3(1): h: 47-56.

Nurjaya dan Wyasa Putra. (2011). Landasan Teoritik Pengaturan LPD. Bali: Udayana University Press.

Onuonga Susan Moraa. (2014). The Analysis of Profitability of Kenya's Top Six Commercial Banks: Internal Factor Analysis. American International Journal of Social Science. Vol. 3 (5), pp. 94-103

Pauzi, Agus. (2011). Analisis Dana Pihak Ketiga, Non Performing Loan, Capital Adequecy Ratio, Dan Loan To Deposit Ratio Terhadap Return On Assets Serta Implikasinya Terhadap Penyaluran Kredit Pada Bank Persero. Fakultas Ekonomi Dan Bisnis Universitas Islam Negeri Syarif Hidayatullah, Jakarta.

Putra, I Wayan Suteja dan Wirajaya, I Gede Ary. (2013). Pengaruh Tingkat Perputaran Kas, Piutang dan Jumlah Nasabah Kredit pada Profitabilitas LPD di Kecamatan Ubud. Jurnal Jurusan Akuntansi Fakultas Ekonomi Universitas Udayana, 3(1): h: 119-135.

Putri, Fifit Syaiful. (2013). Pengaruh Risiko Kredit dan Tingkat Kecukupan Modal terhadap Tingkat Pofitabilitas pada Perusahaan Perbankan yang terdaftar di BEI. Fakultas Ekonomi Universitas Negeri Padang, Padang.

Poposka, Klimentina, and Marko Trpkoski. (2013). Secondary Model for Bank Profitability Management-Test on the Case of Macedonian Banking Sector. Research Journal of Finance and Accounting, 4(6), pp: 216-225.

Shitawati, F. Artin. (2006). Analisis Faktor-Faktor yang Berpengaruh Terhadap Capital Adequacy Ratio (Studi Empiris : Bank Umum di Indonesia periode 2001 - 2004). Program Studi Magister Manajemen, Program Pasca Sarjana, Universitas Diponegoo. Semarang. 
Sianturi, Maria Regina Rosario. (2012). Pengaruh Car, Npl, Ldr, Nim, Dan Bopo Terhadap Profitabilitas Perbankan (Studi Kasus Pada Bank Umum Yang Listed Di Bursa Efek Indonesia Tahun 2007-2011). Fakultas Ekonomi Dan Bisnis Universitas Hasanudin, Mrakasar.

Sudirman, I Wayan. (2013). Manajemen Perbankan Menuju Bankir Konvensional yang Profesional. Jakarta: Kencana Prenada Media Group.

Suryanto, (2017). "Determinants of Profitability in Commercial Banks of Indonesia an Empirical Study". International Journal of Business and Management Review. Vol. 5 (1), pp:1-11, January 2017

Tracey, Mark. (2011). The Impact of Non-performing Loans on Loan Growth: an econometric case study of Jamaica and Trinidad and Tobago, pp:1-22.

Wiagustini, Luh Putu. (2014). Dasar-dasar Manajemen Keuangan. Denpasar: Udayana University Press.

Williams, Harley Tega. (2011). Determinants of Capital Adequacy in The Banking Sub-Sector of the Nigeria Economy: Efficacy of Camels. (A Model Specification with Co-Integration Analysis). International Journal ofAcademic Research in Business and Social Sciences, 1 (3), pp: 233-248.

Yuanjuan, Li dan Xiao Shishun. (2012). Effectiveness of China's Commercial Banks' Capital Adequacy Ratio. Interdisciplinary Journal Of Contemporary Research In Business, 4 (1), pp: 58-68

Yuliani, Puspa Kadek dan Nyoman Sri Werastuti, Desak. (2015). " Pengaruh Loan To Deposit Ratio (LDR), Non Performing Loan (NPL), Return On Assets (ROA) dan Operasional terhadap pendapatan operasional (BOPO) terhadap Capital Adequacy Ratio (CAR) ( Studi Pada Bank Umum Swasta Nasional (BUSN) Devisa)". Universitas Pendidikan Ganesha Singaraja, Indonesia. 